\title{
Balkamra-hipertrófia mértékét jellemzö paraméterek összefüggése MRI-vel meghatározott bal kamrai izomtömeggel hipertrófiás cardiomyopathiában
}

\author{
Nagy Viktória', Pálinkás Attila², Tóth Levente³, Takács Hedvig', \\ Gavallér Henriette', Simor Tamás ${ }^{4}$, Forster Tamás', Sepp Róbert ${ }^{1}$
}

\author{
${ }^{1}$ Szegedi Tudományegyetem, II. sz. Belgyógyászati Klinika és Kardiológiai Központ, Szeged \\ ²Erzsébet Kórház, Belgyógyászati Osztály, Hódmezővásárhely \\ ${ }^{3}$ Pécsi Tudományegyetem, Radiológiai Klinika, Pécs \\ ${ }^{4}$ Pécsi Tudományegyetem, Szívgyógyászati Klinika, Pécs \\ Levelezési cím: \\ Dr. Sepp Róbert, e-mail: sepprobert@gmail.com
}

Háttér: A hipertrófiás cardiomyopathiában ( $\mathrm{HCM})$ észlelhető heterogén mértékű és eloszlású balkamra-hipertrófia $(B K H)$ jellemzésére különböző, részben szemikvantitatív paramétereket használnak a klinikai gyakorlatban. Munkánkban HCM-es betegekben vizsgáltuk a BKH jellemzésére tradicionálisan használt paraméterek és a szív-MRI-vel pontosan meghatározott bal kamrai izomtömeg (BKIT) közötti összefüggést.

Betegek és módszerek: Negyvennégy HCM-es beteget vizsgáltunk (27 férfi, átlagéletkor: $43 \pm 16$ év). A betegeknél standard szív-MRI-vizsgálat történt, a bal kamrai izomtömeg (BKIT $\left.{ }_{M R I}\right)$ meghatározásával. $A$ BKIT ${ }_{M R I}$ és az alábbi BKHát jellemző paraméterek között vizsgáltuk a korreláció mértékét: maximális balkamra-falvastagság $\left(\mathrm{BK}_{\mathrm{max}}\right)$, MaronSpirito-score, Weigle-score, a hipertrofizált BK-szegmensek száma, illetve az echoparaméterek alapján kalkulált bal

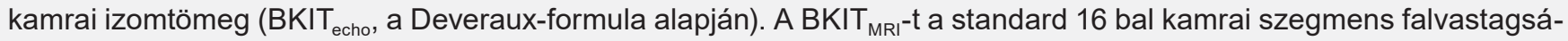
gainak átlagával $\left(\mathrm{BK}_{\text {átlag }}\right)$ is korreláltattuk.

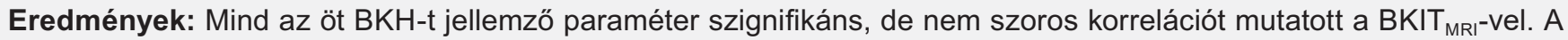
leggyengébb korrelációt a $B K_{\max }$ esetében észleltük ( $\left.r=0,385 ; p=0,01\right)$, a Maron-Spirito-score ugyancsak gyenge kor-

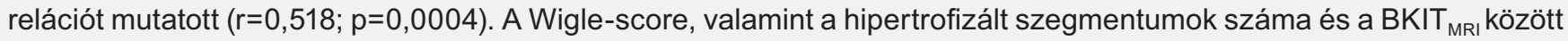
$0,6$ feletti korrelációs koefficienst észleltünk ( $r=0,600, p=0,0001$; illetve 0,643; $p<0,0001)$. A legszorosabb korrelációt a $B K I T_{M R I}$ és az BK átlag mutatta $(r=0,678 ; p<0,0001)$. Bár a BKIT ${ }_{M R I}$ és $B K I T_{\text {echo }}$ között szignifikáns, de gyenge korrelációt tapasztaltunk ( $r=0,445 ; p=0,0028)$, a Bland-Altman-analízis alapján a BKIT echo jelentősen túlbecsüli a valós BKIT-t (átlagos különbség: $-194,9 \mathrm{~g}, \pm 1,96 \mathrm{SD}: 46,0$ illetve $-435,8 \mathrm{~g}$ ).

Következtetés: A balkamra-hipertrófia jellemzésére használt tradicionális paraméterek nem mutatnak szoros korrelációt az MRI-vel meghatározott pontos balkamra-izomtömeg mértékével HCM-es betegekben. Fentiek alapján érdemesnek tűnik a balkamratömeg-index, mint önálló paraméter prognosztikus jelentőségét, és kliniko-morfológiai összefüggéseit vizsgálni hipertrófiás cardiomyopathiában.

Kulcsszavak: hipertrófiás cardiomyopathia, balkamra-tömeg, szív-MRI 


\section{Correlation of left ventricular hypertrophy parameters and MRI derived left ventricular mass in hypertrophic} cardiomyopathy

Background: The magnitude and distribution of left ventricular hypertrophy (LVH) shows a remarkable variety in patients with hypertrophic cardiomyopathy (HCM). To characterise LVH in HCM, several LVH parameters has been traditionally used in clinical practice. In our study we aimed to look for correlation between traditional LVH parameters and MRI derived left ventricular mass (LVM) in patients with HCM.

Patients and methods: The patient study cohort included 44 HCM patients (27 males, average age: $43 \pm 16$ yrs). Cardiac MRI examination was performed according to standard methods and left ventricular mass $\left(\right.$ LVM $\left._{\text {MRI }}\right)$ was determined. Correlation was looked for between $\mathrm{LVM}_{\mathrm{MRI}}$ and the following left ventricular hypertrophy parameters: maximal left ventricular wall thickness $\left(\mathrm{LV}_{\max }\right)$, Maron-Spirito score, Weigle score, number of hypertrophized LV segments, and left ventricular mass calculated from echocardiographic parameters, using the Deveraux equation $\left(\mathrm{LVM}_{\text {echo }}\right)$. $\mathrm{LVM}_{\mathrm{MRI}}$ has been correlated with the average left ventricular wall thickness $\left(L V_{\text {average }}\right.$, defined as the average thickness of the standard 16 left ventricular segments.

Results: All the LVH parameters showed a significant, although not strong correlation with $\mathrm{LVM}_{\mathrm{MR}}$. $\mathrm{LV}_{\max }$, the most frequently used parameter to characterised LVH in HCM, showed the weakest correlation with $\mathrm{LVM}_{\text {MRI }}(r=0.385 ; p=0.01)$, and the Maron-Spirito score showed also a weak correlation $(r=0.518 ; p=0.0004)$. The Wiegle score and the number of hypertrophized LV segments showed a correlation coefficient $\geq 0.6$ ( $r=0.600, p=0.0001 ; 0.643 ; p<0.0001$, respectively). The best correlation was observed between $\operatorname{LVM}_{\mathrm{MRI}}$ and $\mathrm{LV}_{\text {average }}(r=0.678 ; p<0.0001)$. Although a weak, but significant correlation was seen between $\mathrm{LVM}_{\mathrm{MRI}}$ and $\mathrm{LVM}_{\text {echo }}(\mathrm{r}=0.445 ; \mathrm{p}=0.0028)$, according to the Bland-Altman analysis, $\mathrm{LVM}_{\text {echo }}$ markedly overestimate real LVM (average difference: $-194.9 \mathrm{~g}, \pm 1.96$ SD: 46.0 to $-435.8 \mathrm{~g}$ ).

Conclusion: Parameters, traditionally used to characterise left ventricular hypertrophy in HCM, show weak correlation with cardiac MRI derived left ventricular mass in patients with HCM. Therefore, it seems imperative to investigate the prognostic influence and clinico-morphological correlates of LV mass as an independent parameter in patients with hypertrophic cardiomyopathy.

Keywords: hypertrophic cardiomyopathy, left ventricular mass, cardiac MRI

\section{Bevezetés}

A hipertrófiás cardiomyopathia (HCM) jelen ESC-definíció szerint olyan primer, a balkamra hipertrófiájával jellemezett myocardiumbetegség, ahol a hipertrófia mértékét nem magyarázzák egyéb abnormis nyomásviszonyok (1). A HCM az esetek többségében örökletes kórkép, és a familiáris ioncsatorna-betegségekhez (2-4) hasonlóan típusosan Mendeli, autoszomális domináns öröklődést mutat, változó penetranciával és expresszióval. A betegséget 40-60\%-ban specifikus, elsősorban szarkomer fehérjéket kódoló géneket érintő mutációk okozzák (5-13), amelyeket el kell különítenünk más génelváltozások által okozott HCM-fenokópiáktól $(14,15)$.

A hipertrófia lokalizációja, kiterjedése és mértéke nagyfokú heterogenitást mutat HCM-es betegekben $(16,17)$. Típusos esetben a hipertrófia excentrikus, nagyobb mértékben érinti az intraventricularis septumot, mint a bal kamra szabad falát, amely esetben aszimmetrikus septumhipertrófiáról (ASH) beszélünk. A hipertrófia leggyakrabban az interventricularis septum basalis részén a legkifejezettebb, míg máskor a teljes septumra diffúzan kiterjed. Ritkább esetben a hipertrófia a bal kamra apicalis részére (apicalis HCM) vagy a bal kam- ra középső szegmentumára lokalizálódik (mid-ventricularis HCM), de elöfordulhat, hogy a hipertrófia diffúz, koncentrikus formában jelentkezik $A$ balkamra-hipertrófia lokalizációjának jellemzésére szolgál az ún. Maron-klasszifikáció (18).

A balkamra-hipertrófia mértékének és kiterjedésének jellemzésére számos paramétert és score-rendszert dolgoztak ki. A klinikai gyakorlatban a legegyszerübb, és leginkább használt ilyen paraméter a maximális balkamra-falvastagság $\left(\mathrm{BK}_{\max }\right)$, amely a bal kamrai szegmentumok bármelyikében mért legnagyobb bal kamrai falátmérőt jelenti. Egy másik rendszer a hipertrofizált ( $\geq 15 \mathrm{~mm}$ ) szegmentumok számát veszi alapul: enyhének definiálja a hipertrófiát amennyiben csak egy kamrai szegmentum érintett, középsúlyosként, amennyiben kettő, és súlyosként, ha három vagy több szegmentum érintett. Ismert az ún. Maron-Spirito-score is (balkamra-falvastagság-index), amely a bal kamrát négy szegmentumra osztja (anterior, laterális, inferior, septalis), és a szegmentumok bármely magasságában mért maximális balkamrafal-átmérök összegeként jellemzi a teljes balkamra-hipertrófia mértékét (19). Összetettebb score-rendszer a Wigle-score (1. táblázat), amely a hipertrófia mértékén és apex felé való kiterjedtségének pontozásán alapul (20). 
1. TÁBLÁZAT. A Wigle-score pontrendszere a balkamrahipertrófia szemikvantitatív jellemzésére hipertrófiás cardiomyopathiában
A hipertrófia kiterjedtsége

\begin{tabular}{|l|c|c|}
\hline & $15-19$ & 1 \\
\hline Septumvastagság $(\mathrm{mm})$ & $20-24$ & 2 \\
\hline (a septum basalis 1/3-a) & $25-29$ & 3 \\
\hline & $>30$ & 4 \\
\hline
\end{tabular}

A hipertrófia kiterjedése a papilláris izmok szintjéig (a septum basalis 2/3-a)

A hipertrófia kiterjedése a csúcsig (teljes septumérintettség)

A hipertrófia kiterjedése az anterolaterális falra

Összesen
2

2

2

10
A HCM elsődleges morfológiai jellegzetessége és a betegség lényege a más okból nem magyarázható, primer myocardiumhipertrófia, amely a balkamra-hipertrófia (BKH) mértékével, a bal kamrai izomtömeggel (BKIT) jellemezhető. Ennek megfelelően a balkamra-hipertrófia szemikvantitatív paraméterei és a HCM patofiziológiai-klinikai jellemzői közötti kapcsolódást már számos esetben, vizsgálták, összefüggéseket keresve pl. a BKH és diasztolés diszfunkció mértéke, a pitvarfibrilláció kialakulása, a kamrai tachycardiák jelentkezése, a hirtelen szívhalál bekövetkezte, vagy a szívelégtelenségbe való progresszió szempontjából (21-30). Utóbbi vizsgálatokban fenti, echokardiográfiás paramétereket használták a $\mathrm{BKH}$ jellemzésére, mint pl. a $\mathrm{BK}_{\max }$, Maron-Spirito-score vagy Wigle-score. Fenti vizsgálatok eredményei tehát nem a valós balkamra-hipertrófia (balkamra-izomtömeg) tényleges mértékével, hanem az ezt közelítően jellemző echokardiográfiás paraméterekkel való összehasonlításokon alapulnak.

Fentiek alapján célkitüzésünk volt, hogy a balkamra-hipertrófia jellemzésére használt echokardiográfiás paraméterek, valamint az MRI-vel meghatározott tényleges bal kamrai izomtömeg közötti összefüggést vizsgáljuk hipertrófiás cardiomyopathiás betegekben. Vizsgáltuk továbbá a balkamra-izomtömeg mértékének meghatározására általánosságban használt Deveraux-formula alkalmazhatóságát ezen betegcsoportban.

\section{Betegek és módszerek}

\section{Betegek}

A vizsgálatot a Szegedi Tudományegyetem Szent-Györgyi Albert Klinikai Központ Regionális Humán Orvosbiológiai Tudományos és Kutatásetikai Bizottsága a 165/2016-SZTE számon engedélyezte. Mindegyik beteg előzetes tájékoztatás alapján beleegyezett a vizsgálatba.

Az SZTE II. sz. Belgyógyászati Klinika és Kardiológiai Központban gondozott, 44 hipertrófiás cardiomyopa- thiában szenvedő beteg került vizsgálatra, konszekutív módon. A betegek közül 27 volt férfi (61\%), átlagéletkoruk $43 \pm 16$ év volt. $A$ betegekben echokardiográfiával mért maximális bal kamrai falvastagság $\left(\mathrm{BK}_{\max }\right) 28 \pm 6$ $\mathrm{mm}$ (16-39 mm) volt. Tizenegy betegben (25\%) észleltünk szignifikáns bal kamra kifolyótraktus gradienst, az obstruktív betegekben a nyugalmi csúcsgradiens $56 \pm 32$ Hgmm (34-120 Hgmm) volt. Mindegyik beteg sinusritmusban volt, két betegben bal Tawara-szár-blokkot észleltünk. A vizsgálatba való bevonáskor nem választottunk be olyan betegeket, akikben korábban ICD- vagy pacemaker- (PM) beültetés történt, de a kivizsgálás során meghatározott magas hirtelen szívhalál rizikóstátusz alapján 6 betegben a későbbiekben ICD-implantáció történt (5 esetben primer, 1 esetben szekunder prevenciós indikációval). A későbbiekben percutan transluminalis septalis myocardiumabláción (PTSMA) átesett betegekben mind az echokardiográfiás, mind az MRI-vizsgálat az ablációt megelőzően történt.

\section{Módszerek}

A betegekben standard módon 2D- és Doppler-echokardiográfia történt, standard parasternalis rövid- és hossztengelyű, valamint apicalis 2-, 3- és 4-üregi nézetekben. A bal kamra 16-szegmentumos modelljét használva, mindegyik szegmensben megmértük a végdiasztolés falvastagság átmérőjét a parasternalis rövid tengelyi nézetekben a mitralis billentyü-, a papillaris izom síkjában és a csúcsnál. $A$ végdiasztolét EKG-kapuzással határoztuk meg, az R-hullám csúcsánál. Utóbbiakon kívül további standard echoparamétereket határoztunk meg (aortagyöki, bal pitvari, végdiszatolés és végszisztolés átmérők, bal kamrai ejekciós frakció, mitralis és tricuspidalis insufficientia mértéke, balkamra-kifolyótraktus-gradiens mértéke).

Az echokardiográfiás vizsgálattól számított három hónapon belül minden betegben standard MRI-vizsgálat történt, 1-1.5 teslás MRI-rendszereken. A szív-MR-felvételek kilégzés végi állapotban készültek, EKG triggerelt módon, $\mathrm{T}_{1}$-súlyozással, 0-40 msec-mal az R-hullám után. Szívciklusonként 25 fázist örökítettünk meg, 10 mm-es szeletvastagságokkal. Az alkalmazott MR-szekvenciák rövidtengelyi, longitudinális négyüregi, vertikális kétüregi és jobbkamra-kifolyási traktus nézetekből tartalmazták a többszeletes, többfázisú mozgóképek felvételeiket. A többszeletes, rövid tengelyt ábrázoló videók felvételi tartománya az AV-billentyűk szintje feletti síktól a szívcsúcs szintjéig terjedt. A balkamra-izomtömeg meghatározása (BKIT $\mathrm{MRI}_{\text {) }}$ ) rövidtengelyi síkokból, az endo- és epicardialis kontúr meghatározásával, planimetriával történt, a MASS-szoftver alkalmazásával. Az endokardiális és az epikardiális kontúr közötti terület felelt meg a miokardiális izom volumenének, amelyet a szoftver a rövidtengelyi nézetből a kontúrok által kijelölt összterület és a szeletvastagság szorzataként határozott meg, amelyből a szívizom tömege adódott. 
2. TÁBLÁZAT. A balkamra-hipertrófiát jellemző paraméterek és az MRI-vel meghatározott balkamra-tömeg közötti korreláció

\begin{tabular}{|l|c|c|}
\hline Hipertrófia-paraméter & $\begin{array}{c}\text { Korreláció } \\
\text { (r v. rho) }\end{array}$ & $\begin{array}{c}\text { Szignifi- } \\
\text { kancia }\end{array}$ \\
\hline $\begin{array}{l}\text { Maximális BK-falvastagság } \\
\left(\mathrm{BK}_{\max }\right)\end{array}$ & 0,385 & $\mathrm{p}=0,01$ \\
\hline $\begin{array}{l}\text { Hipertrofizált } \\
\text { BK-szegmentumok száma }\end{array}$ & 0,643 & $\mathrm{p}<0,0001$ \\
\hline $\begin{array}{l}\text { Bal kamrai falvastagság-index } \\
\text { (Maron-Spirito-score) }\end{array}$ & 0,518 & $\mathrm{p}=0,0004$ \\
\hline Wigle-score & 0,600 & $\mathrm{p}=0,0001$ \\
\hline Átlagos BK-falvastagág $\left(\mathrm{BK}_{\text {átlag }}\right)$ & 0,678 & $\mathrm{p}<0,0001$ \\
\hline
\end{tabular}

\section{Adatelemzés}

Az echokardiográfiás alapadatokból a következő, balkamra-hipertrófia jellemzésére használt paramétereket határoztuk meg:

1. maximális balkamra-falátmérő $\left(B K_{\max }\right)$ : a bal kamrai szegmentumok bármelyikében mért legnagyobb bal kamrai falátmérő;

2. a hipertrofizált ( $\geq 15 \mathrm{~mm}$ ) szegmentumok száma;

3. Maron-Spirito-score (balkamra-hipertrófia-index): a bal kamrát négy szegmentumra osztva (anterior, laterális, inferior, septalis), a szegmentumok bármely magasságában mért maximális balkamrafal-átmérők összege (19);

4. Wigle-score: összetett score-rendszer (1. táblázat), amely a hipertrófia mértékén és szívcsúcs felé való kiterjedtségének pontozásán alapul (21).

Fentieken kívül a 16 balkamra-szegmens falátmérőinek átlagát is meghatároztuk ( $\left(\mathrm{BK}_{\text {átlag }}\right)$. Az echokardiográfiás alapadatokból a balkamra-izomtömeget a Deveraux-formula (31) segítségével számítottuk ki (BKIT $T_{\text {echo }}$ ).

\section{Statisztika}

A folyamatos változókat átlag $\pm S D$ formában fejeztük ki. Az MRI-vel meghatározott bal kamrai izomtömeg és az echokardiográfiával meghatározott adatokból számított hipertrófiaindexek közötti korrelációt lineáris regressziós analízissel vizsgáltuk. A 0,05-nél kisebb p-értéket tekintettük statisztikailag szignifikánsnak. A bal kamrai izomtömeg MRI-vel meghatározott és az echokardiográfiás paraméterekből Deveraux-formulával számolt értékeit a regressziós vizsgálaton kívül a Bland-Altman-analízissel is vizsgáltuk.

\section{Eredmények}

\section{Az MRI-vel meghatározott bal kamrai izomtömeg és az echokardiográfiával meghatározott balkamra-hipertrófia indexek összehasonlítása}

Mind az öt, szegmentális echokardiográfiás adatokból számított balkamra-hipertrófiát jellemző paraméter szignifikáns korrelációt mutatott az MRI-vel meghatározott balkamra-tömeggel (2. táblázat). Mindazonáltal, a korrelációs koefficiens értéke egyik esetben sem érte el a 0,7-et, így a korreláció mértéke egyik esetben sem volt különösen erős. A leggyengébb korrelációt a balkamra-hipertrófia jellemzésére leggyakrabban használt paraméter, a maximális bal kamrai falvastagság $\left(\mathrm{BK}_{\max }\right)$ esetében észleltük ( $r=0,385 ; p=0,01 ; 1$. ábra $A$-panel). A szintén gyakran használt index, a Maron-Spirito-score ugyancsak gyenge korrelációt mutatott a balkamra-tömeggel ( $r=0,518 ; p=0,0004 ; 1$. ábra, B-panel). A Wigle-score, valamint a hipertrofizált szegmentumok száma és a balkamra-tömeg között azonban 0,6 feletti korrelációs koefficienst észleltünk $(=0,600, p=0,0001$; 1. ábra C-panel, illetve 0,$643 ; p<0,0001 ; 1$. ábra, $D$-panel).

A legszorosabb korrelációt az eddig nem használt paraméter, a 16 bal kamra szegmentum falvastagságának átlaga, a $\mathrm{BK}_{\text {átlag }}$ adta $(\mathrm{r}=0,678 ; \mathrm{p}<0,0001 ; 2$. ábra).

\section{Az MRI-vel meghatározott bal kamrai izomtömeg és az echokardiográfiás adatokból számított bal kamrai izomtömeg} összehasonlítása

A bal kamrai izomtömeg MRI-vel és a Deveraux-formulával meghatározott értéke között szignifikáns, de gyenge korrelációt találtunk $(r=0,445 ; p=0,0028 ; 3$. ábra, A-panel). Mindazonáltal a Bland-Altman-analízis azt mutatta, hogy az echokardiográfiás paraméterek alapján kalkulált érték jelentősen, mintegy 200 g-mal túlbecsüli a valós bal kamrai izomtömeg értékét (-194,9 g, $\pm 1,96$ SD: $-435,8$ - 46,0 g; 3. ábra; B-panel).

\section{Megbeszélés}

Munkánk a szegmentális balkamra-falvastagság echokardiográfiával mért és ezen adatok alapján kalkulált hipertrófia score-ok és az MRI-vel meghatározott tényleges balkamra-izomtömeg közötti korrelációt vizsgálta. Eredményeink szerint a korreláció a tradicionális BKH-paraméterek és a valós BK-izomtömeg között gyenge vagy közepes erősségű; a leggyengébb pedig az eddig leggyakrabban használt balkamra-hipertrófia paraméter, a maximális bal kamrai falvastagság esetén. Olivotto és munkatársai $264 \mathrm{HCM}$-es beteget vizsgálva saját vizsgálatukban hasonlóképpen alacsony korrelációs koefficiens értéket $\left(r^{2}=0,38\right)$ kaptak a maximális BK-falvastagság és a bal kamrai tömegindex között (32). Utóbbi nem meglepő, hiszen a maximális BK-falátmérő balkamra-hipertrófia mértékét egyetlen mért adattal próbálja jellemezni. Megfigyelhető, hogy amennyiben egyre több mérés adatát inkorporáljuk az adott hipertrófia-indexbe (pl. Maron-Spirito-score, Wigle-score), annál magasabb korrelációs értéket kapunk. Mindez a balkamra-hipertrófia kiterjedtségének és heterogenitásának egyenes következménye. Ered- 

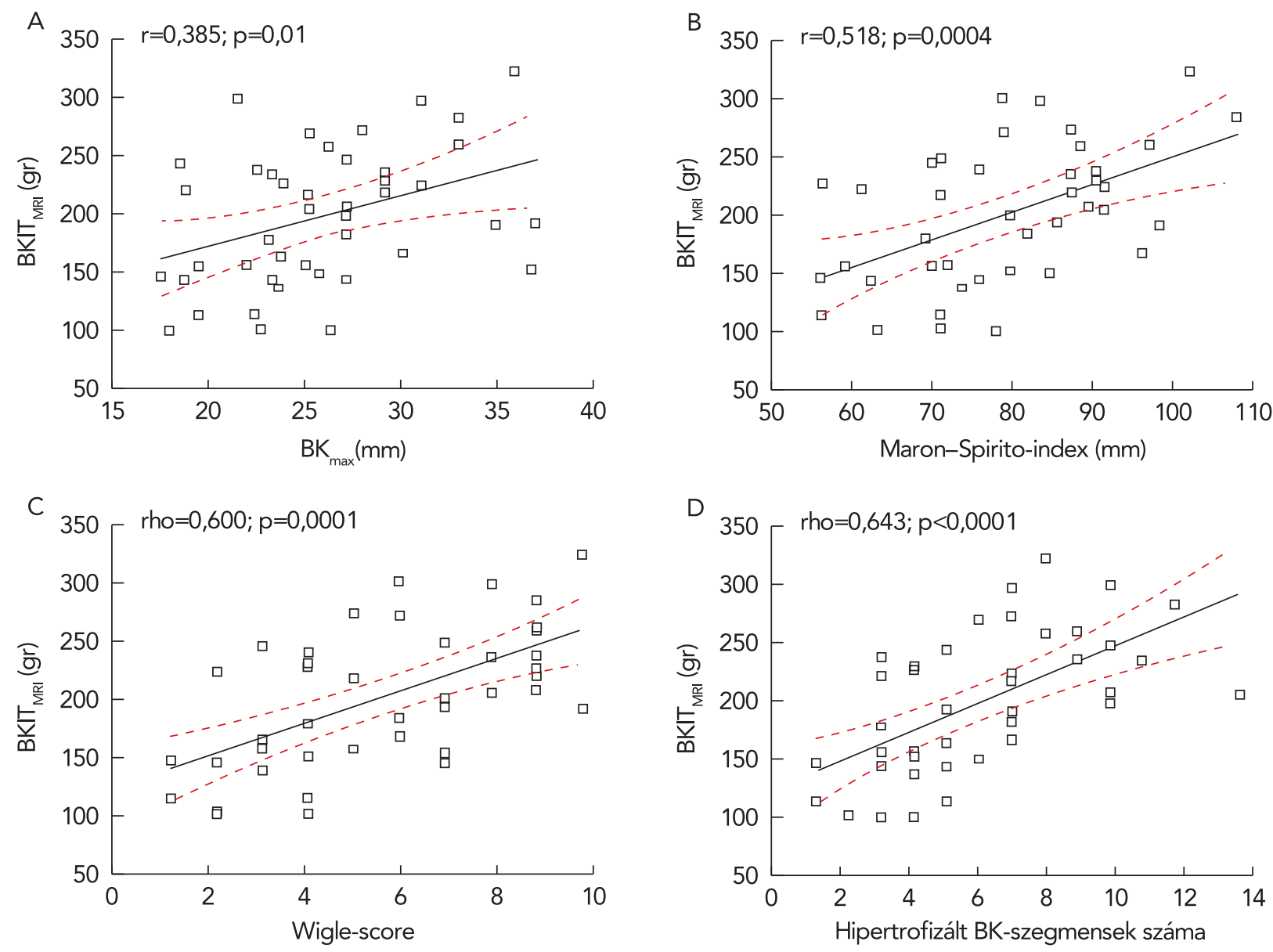

1. ÁBRA. Korreláció az MRI-vel meghatározott balkamra-izomtömeg (BKIT $\left.{ }_{\mathrm{MRI}}\right)$ és a maximális bal kamrai falvastagság ( $\mathrm{BK}_{\max }$ A-panel), a Maron-Spirito-score (B-panel), a Wigle-score (C-panel) és a hipertrófizált BK-szegmensek száma (D-panel) között

ményeink mindazonáltal arra utalnak, hogy korábban a HCM klinikai eltérései és lefolyása szempontjából vizsgált balkamra-hipertrófia score-ok a balkamra-hipertrófia tényleges mértékét nem megfelelően jellemzik,

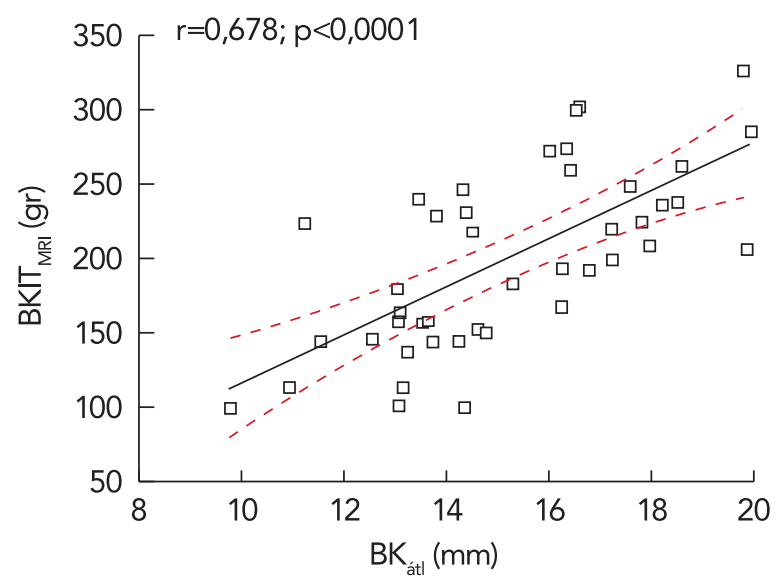

2. ÁBRA. Korreláció az MRI-vel meghatározott balkamraizomtömeg (BKIT $\mathrm{MR}_{\mathrm{I}}$ ) és 16 balkamra-szegmentum falvastagságának átlaga ( $\left.\mathrm{BK}_{\text {átlag }}\right)$ között így a korábbi vizsgálatok eredményei fenti összefüggésben nem megbízhatóak. Különösen lényeges lehet ez azon jellemzők esetén, ahol a balkamra-hipertrófia globális mértéke elvileg meghatározó lehet, mint pl. a diasztolés diszfunkció mértéke vagy szívelégtelenségbe való progresszió esetén.

Eredményeink szerint az echokardiográfiás paraméterek alapján kalkulált bal kamrai izomtömeg és annak MRI-vel meghatározott tényleges mértéke között is jelentős különbség van, előbbi utóbbit jelentősen túlbecsüli. Ez nem meglepő, hiszen a Deveraux-képlet alapján számolt bal kamrai izomtömeg két falvastagság értéket inkorpolál a képletbe, amely lényegileg uniformis balkamra-falvastagságot és szabályos balkamra-geometriát feltételez, amely HCM esetén azonban nem így van. Ez elemi meggondolások alapján is feltételezhető, de a Deveraux-formula alapján meghatározott balkamra-izomtömeg, mint klinikai paraméter számos alkalommal feltünik HCM-mel kapcsolatos közleményekben. Ennek tételes cáfolata, amely eredményeinkből kitűnik, eddig hiányzott a szakirodalomból.

A balkamra-hipertrófia meghatározásának különös jelentőséget adtak azok a vizsgálatok, amelyek azt 

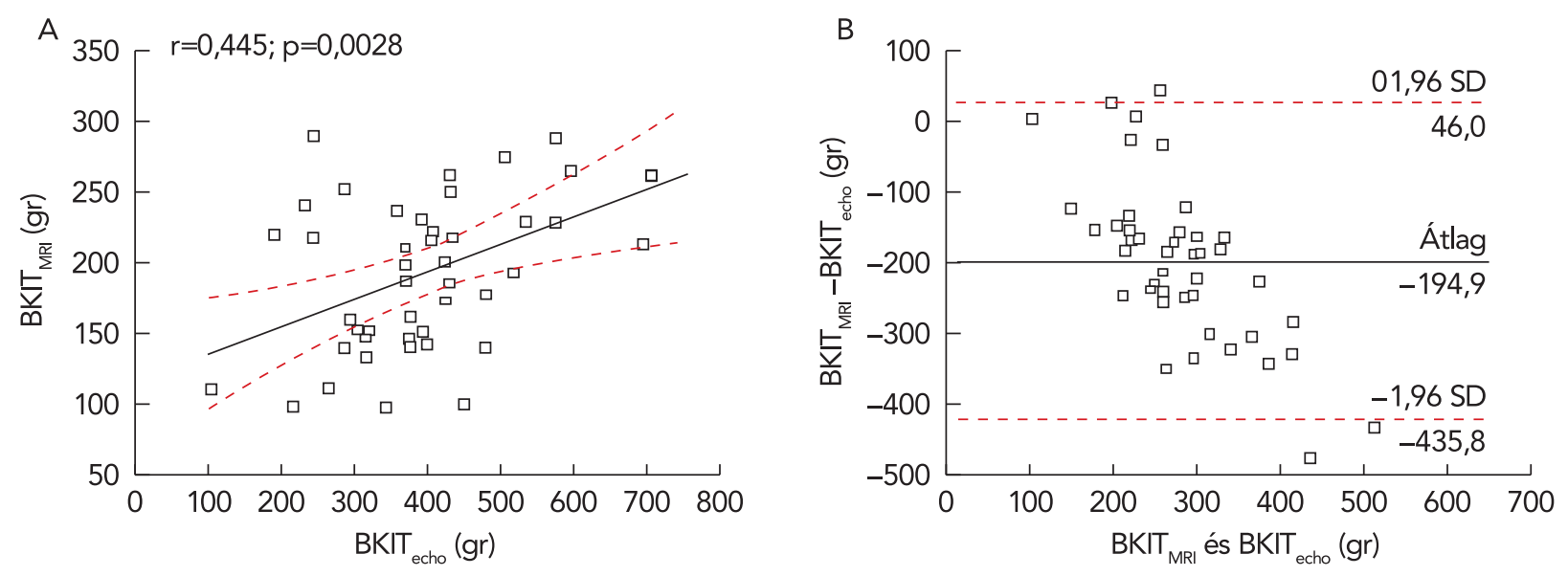

3. ÁBRA. Korreláció az MRI-vel meghatározott bal kamra izomtömeg (BKIT $\mathrm{MRI}_{1}$ és a Deveraux-formulával, echokardiográfiás

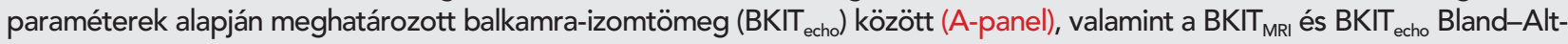
man-analízise (B-panel)

igazolták, hogy a maximális BK-falvastagság a betegségben megfigyelhető hirtelen szívhalál prediktora és a maximális BK-falvastagság $>30 \mathrm{~mm}$ feletti mértéke hirtelen szívhalál-rizikót jelent $(21,28,29$, 33). A BK-falvastagság mértékét jelen hirtelen szívhalál prediktáló algoritmusok is figyelembe veszik (1). Utóbbi szempontból érdekes adat, hogy Olivotto és munkatársai 256 beteget felölelő vizsgálatában az MRI-vel meghatározott BK-izomtömeg-index az adverz kardiális kimenetel szempontjából szenzitívebb paraméter volt (100\%, 39\%-os specificitással), mint a $>30 \mathrm{~mm} \mathrm{BK}_{\max }$, ami pedig specifikusabbnak bizonyult fenti tekintetben (90\%, 41\%-os szenzitivitással) (32). Vizsgálatukban $10 \mathrm{HCM}$-mel kapcsolatos haláleset fordult elö, akikben a BK-tömegindex szignifikánsan magasabb volt, mint a túlélőkben, és mindegyikük abban az alcsoportban volt, ahol a BK-tömegindex jelentősen emelkedett volt. A közel normális vagy mérsékelten emelkedett BK-tömegindexü alcsoportban haláleset nem fordult elő. Egy későbbi, japán vizsgáltban nem találtak összefüggést a BK-tömegindex és a klinikai kimenetel között, de abban lényegesen alacsonyabb esetszámú (109 beteg) betegcsoportot vizsgáltak (34).

\section{Következtetések}

A balkamra-hipertrófia jellemzésére használt paraméterek szignifikáns, de túlnyomórészt gyenge, vagy közepesen erős korrelációt mutatnak csak a bal kamrai izomtömeg MRI-vel meghatározott értékével. Az eltérés különösen jelentős az echokardiográfia alapján kalkulált és az MRI alapján mért bal kamrai izomtömeg között. Fentiek alapján érdemesnek tủnik a balkamratömeg-index, mint önálló paraméter prognosztikus jelentőségét és kliniko-morfológiai összefüggéseit vizsgálni hipertrófiás cardiomyopathiában.

\section{Köszönetnyilvánítás}

A munka a „Ritka betegségek patogenezisének kutatása, új diagnosztikai és terápiás eljárásokat megalapozó fejlesztések" (GINOP-2.3.2-15-2016-00039), az „Életet veSzélyezTető Akut megbetegedések súlYossági és hALálozási mutatólnak jaVítása transzlációs orvostudományi mEgközelítésben - STAY ALIVE" (GINOP-2.3.2-15-2016-00048) és a Szegedi Tudományegyetem ÁOK Kari Kutatási Alap „Hetényi Géza” pályázatának támogatásával készült.

\section{Irodalom}

1. Elliott PM, Anastasakis A, Borger MA, et al. 2014 ESC Guidelines on diagnosis and management of hypertrophic cardiomyopathy: the Task Force for the Diagnosis and Management of Hypertrophic Cardiomyopathy of the European Society of Cardiology (ESC). Eur Heart J. 2014; 35: 2733-2779. doi: 10.1093/eurheartj/ehu284

2. Sepp R, Hategan L, Bácsi A, et al. Timothy Syndrome 1 Genotype without Syndactyly and Major Extracardiac Manifestations. Am J Med Genet A. 2017; 173(3): 784-789. doi: 10.1002/ajmg.a.38084. 3. Hategan L, Csányi B, Ördög B, et al. A novel 'splice site' HCN4 gene mutation, c.1737+1 G>T, causes familial bradycardia, reduced heart rate response, impaired chronotropic competence and increased short-term heart rate variability. Int J Cardiol 2017; 241: 364372. doi: 10.1016/j.ijcard.2017.04.058

4. Ördög B, Hategan L, Kovács $M$, et al. Identification and functional characterisation of a novel KCNJ2 mutation, Val302del, causing Andersen-Tawil syndrome. Can J Physiol Pharmacol 2015; 93(7): 569-75. doi: 10.1139/cjpp-2014-0527.

5. Geisterfer-Lowrance AAT, Kass S, Tanigawa G, et al. A molecular basis for familial hypertrophic cardiomyopathy: a beta cardiac myosin heavy chain gene missense mutation. Cell 1990; 62: 999-1006. 6. Thierfelder L, Watkins H, MacRae C, et al. Alpha-tropomyosin and cardiac troponin T mutations cause familial hypertrophic cardiomyopathy: a disease of the sarcomere. Cell 1994; 77: 701-712.

7. Bonne G, Carrier L, Bercovici J, et al. Cardiac myosin binding protein-C gene splice acceptor site mutation is associated with familial hypertrophic cardiomyopathy. Nat Genet 1995; 11: 438-440.

8. Watkins H, Conner D, Thierfelder L, et al. Mutations in the cardiac myosin binding protein-C gene on chromosome 11 cause familial hypertrophic cardiomyopathy. Nat Genet 1995; 11: 434-437. 
9. Toth T, Nagy V, Faludi R, et al. The GIn1233ter mutation of the myosin binding protein $\mathrm{C}$ gene: Causative mutation or innocent polymorphism in patients with hypertrophic cardiomyopathy? Int J Cardiol 2011; 153(2): 216-9. doi: 10.1016/j.ijcard.2011.09.062.

10. Kimura A, Harada H, Park J-E, et al. Mutations in the troponin I gene associated with hypertrophic cardiomyopathy. Nature Gen 1997; 16: 379-382.

11. Poetter K, Jiang H, Hassanzadeh S, et al. Mutations in either the essential or regulatory light chains of myosin are associated with a rare myopathy in human heart and skeletal muscle. Nat Genet 1996; 13: $63-69$.

12. Mogensen J, Klausen I, Pedersen A, et al. Alpha-cadiac actin is a novel disease gene in familial hypertrophic cardiomyopathy. J Clin Invest 1999; 103: R39-R43.

13. Satoh M, Takahashi M, Sakamoto T, Hiroe M, Marumo F, Kimura A. Structural analysis of the titin gene in hypertrophic cardiomyopathy: identification of a novel disease gene. Biochem Biophys Res Commun 1999; 262: 411-417.

14. Csanyi B, Popoiu A, Hategan L, et al. Identification of two novel LAMP2 gene mutations in Danon disease. Can J Cardiol 2016; 32(11): 1355.e23-1355.e30. doi: 10.1016/j.cjca.2016.02.071.

15. Csányi B, Hategan L, Nagy V, et al. Identification of a Novel GLA Gene Mutation, p.lle239Met, in Fabry Disease with a Predominant Cardiac Phenotype. Int Heart J 2017; 58(3): 454-458. doi: 10.1536/ ihj.16-361

16. Klues HG, Schiffers A, Maron BJ. Phenotypic spectrum and patterns of left ventricular hypertrophy in hypertrophic cardiomyopathy: morphologic observations and significance as assessed by twodimensional echocardiography in 600 patients. J Am Coll Cardiol 1995; 26(7): 1699-708.

17. Maron MS, Maron BJ, Harrigan C, et al. Hypertrophic cardiomyopathy phenotype revisited after 50 years with cardiovascular magnetic resonance. J Am Coll Cardiol 2009; 54(3): 220-8.

18. Maron BJ, Gottdiener JS, Epstein SE. Patterns and significance of distribution of left ventricular hypertrophy in hypertrophic cardiomyopathy. A wide angle, two dimensional echocardiographic study of 125 patients. Am J Cardiol 1981; 48: 418-28.

19. Spirito P, Maron BJ, Chiarella F, Bellotti P, Tramarin R, Pozzoli M, Vecchio C: Diastolic abnormalities in patients with hypertrophic cardiomyopathy: relation to magnitude of left ventricular hypertrophy. Circulation 1985; 72: 310-6.

20. Wigle ED, Sasson Z, Henderson MA, et al. Hypertrophic cardiomyopathy: the importance of the site and the extent of hypertrophy: a review. Prog Cariovasc Dis 1985; 28: 1-83.

21. Spirito P, Maron BJ. Relation between extent of left ventricular hypertrophy and occurance of sudden cardiac death in hypertrophic cardiomyopathy. J Am Coll Cardiol 1990; 15(7): 1521-6.
22. Spirito P, Watson RM, Maron BJ. Relation between extent of left ventricular hypertrophy and occurance of ventricular tachycardia in hypertrophic cardiomyopathy. Am J Cardiol 1987; 60(14): 1137-42.

23. Spirito P, Maron BJ. Relation between extent of left ventricular hypertrophy and diastolic filling abnormalities in hypertrophic cardiomyopathy. J Am Coll Cardiol 1990; 15(4): 808-13.

24. Spirito P, Maron BJ. Relation between extent of left ventricular hypertrophy and age in hypertrophic cardiomyopathy. J Am Coll Cardiol 1989; 13(4): 820-3.

25. Spirito P, Lakatos E, Maron BJ. Degree of left ventricular hypertrophy in patients with hypertrophic cardiomyopathy and chronic atrial fibrillation. Am J Cardiol 1992; 69(14): 1217-22.

26. Maron MS, Zenovich AG, Casey SA, et al. Significance and relation between magnitude of left ventricular hypertrophy and heart failure symptoms in hypertrophic cardiomyopathy. Am J Cardiol 2005; 95(11): 1329-33.

27. Dritsas A, Gilligan D, Sbarouni E, et al. Influence of left ventricular hypertrophy and function on the occurrence of ventricular tachycardia in hypertrophic cardiomyopathy. Am J Cardiol 1992; 70(9): 913-6.

28. Spirito $P$, Bellone $P$, Harris KM, et al. Magnitude of left ventricular hypertrophy and risk of sudden death in hypertrophic cardiomyopathy. N Engl J Med 2000; 342(24): 1778-85.

29. Olivotto I, Gistri R, Petrone P, et al. Maximum left ventricular thickness and risk of sudden death in patients with hypertrophic cardiomyopathy. J Am Coll Cardiol 2003; 41(2): 315-21.

30. Maron BJ, Casey SA, Hurrell DG, et al. Relation of the left ventricular thickness to age and gender in hypertrophic cardiomyopathy. Am J Cardiol 2003; 91: 1195-8.

31. Devereux RB, Reichek N. Echocardiographic determination of left ventricular mass in man. Anatomic validation of the method. Circulation 1977; 55: 613-8.

32. Olivotto I, Maron MS, Autore C, et al. Assessment and significance of left ventricular mass by cardiovascular magnetic resonance in hypertrophic cardiomyopathy. J Am Coll Cardiol 2008; 52(7): 559-66.

33. Orosz A, Baczko I, Nagy V, Gavaller H, Csanady M, Forster T, Papp JG, Varro A, Lengyel C, Sepp R. Short-term beat-to-beat variability of the QT interval is increased and correlates with parameters of left ventricular hypertrophy in patients with hypertrophic cardiomyopathy. CANADIAN JOURNAL OF PHYSIOLOGY AND PHARMACOLOGY 2015; 93(9): 765-772.

34. Miyaji $Y$, Iwanaga $Y$, Nakamura $T$, et al. Interrelationship between the myocardial mass, fibrosis, BNP, and clinical outcomes in hypertrophic cardiomyopathy. Intern Med 2016; 55: 1261-1268. doi: 10.2169/internalmedicine.55.6480) 